through the maiotic phase, they, of course, possess only half the somatic number of chromosomes. It has therefore always been assumed that herein there existed a difference between the cycle of cell generations of multicellular animals and plants, for while in animals those cells which have reduced are all converted directly into sexual elements, in plants only a few such cells may become converted into sexual cells, the rest performing the functions of supporting and nourishing the few. Moreover, in plants apparently any

FIG. 2.

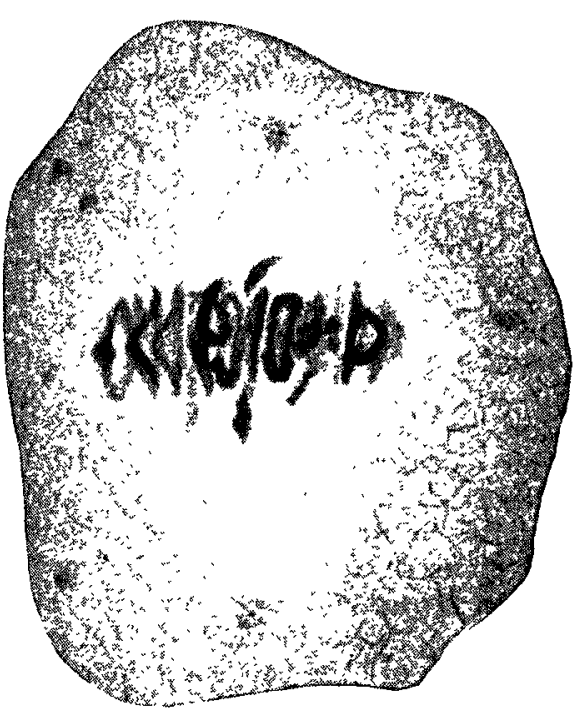

$\Delta$ first maiotic (heterotype) division figure. Therelare onehalf the number of chromosomes found in the somatic division. The chromosomes are in various definite forms.

number of generations of cells may intervene between reduction and the production of sexual elements.

The observations recorded in a communication to the Royal Society on the Life History of Leucocytes by myself claim to show that in the generations of leucocytic cells we have phenomena which run more or less parallel with the post-maiotic (reduced) generations that exist in prothallial tissue in plants. It is first explained that the term leucocyte is intended to include all the wandering nucleated cells of the animal body. In the male sexual gland the sequence of events among those cells that are destined to be sexual

FIG. 3.

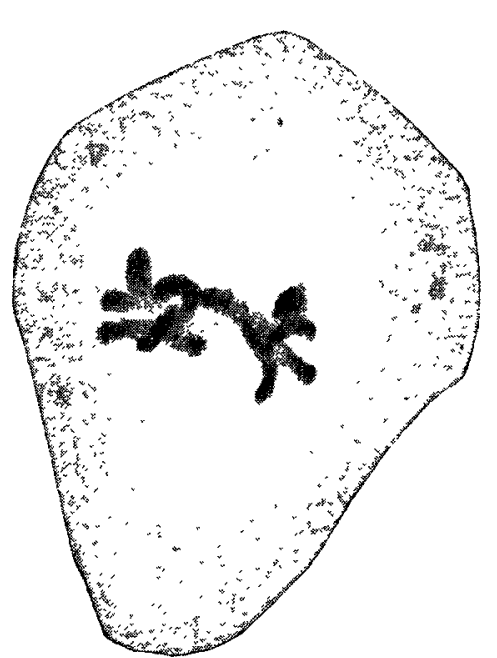

A second maiotic (homotype) division figure. The chromosomes are in the same form as in the somatic division but are found to be only one-half the somatic number. This type of division is the most common among the cells of the bone marrow.

elements is as follows. Up to a certain point the cells in question divide in a similar manner to the cells forming the ordinary body tissues and exhibit the full somatic number of chromosomes. This is known as the somatic type of division. The somatic are followed by amitotic divisions. That is without the appearance of any spindle figure or chromosomes $-a$ similar division, in fact, to that of a drop of viscous fluid into two drops. After this come further somatic divisions, followed immediately by the first and second maiotic divisions. The cells resulting are converted directly into sexual elements. Among the leucocytes and their immediate ancestors a very similar series of events occurs.
First we have amitosis and somatic mitoses alternating with each other just as in reproductive tissue. Then follow divisions which are similar to the first and second maiotic divisions, where the chromosomes are reduced in number to one-half of that found in the somatic cells. Here the similarity to animal reproductive cells ends and that to the reduced tissues in plants begins. Apparently there is an unlimited number of post-maiotic generations among the leucocytic cells. Furthermore, in another communication to the Royal Society ${ }^{2}$ it is claimed that these reduced leucocyte cells may produce tissues possessing characters and functions similar to somatic tissues. If these observations are correct we have therefore a further parallel between the phenomena exhibited by animal and vegetable cells. The reduced cells of both animals and plants are out of coördination with the soma from which they have been derived. I consider that the evidence in this respect with regard to leucocytes is in favour of the correctness of my observations.

The bearing of these observations upon what happens in malignant growths may here be mentioned. It has been recorded ${ }^{3}$ elsewhere that one of the earliest phenomena in the occurrence of malignant tumours is the invasion of the tissue cells by leucocytes with the subsequent common division of both nuclei. This produces a race of hybrid cells, half tissue cell, half leucocyte. It has also been recorded by the same authors that the cells of malignant growths reduce in a similar manner to the cells of reproductive tissues. All the forms of cell division seen in malignant tissue are also seen in normal leucocytic tissue, and both leucocytes and malignant tissue are out of coördination with the true soma. According to the present observations, then, the hybrid cells act just as would be expected and possess the characteristics, to a certain extent, of both their ancestors.

Liverpool.

\section{ACUTE LOBAR PNEUMONIA IN A PYGMY.}

\section{BX W. HERBERT GREGORY, M.D., C.M. EDIN.}

ON the evening of Oct. 14th, 1905, I was asked by Colonel J. J. Harrison to see one of the pygmies whom he brought back from the Ituri Forest. I found the patient, Matuha by name, a male, stated to be aged 23 years, lying on a mattress. ${ }^{4}$ His temperature was $103.2^{\circ} \mathrm{F}$, his pulse was 120 , and his respirations were 20. By the aid of an interpreter it was found that he complained of pain in the left infra-axillary region. Three days before the patient had suddenly stopped dancing in the middle of a performance, complaining that he was tired and that his back hurt him. He was seen by a medical man and treated for a sprained muscle. No evidence of a rigor could be obtained, but the difficulty of getting any evidence of prodromata was considerable.

On Oct. 15th the temperature was $103^{\circ}$, the respirations were 24 , and the pulse was 118 , with a dry hacking cough. There was a small amount of albumin in the urine. On examination, slight dulness with some fine crepitations and rhonchi were found over the base of the left lung. There were also rhonchi over the right base, but these disappeared in a day or two. On the 16th the dulness had increased and the inflammation finally involved the whole of the lower lobe of the left lung. He was at first treated with a mixture containing one and a half drachms of antimonial wine, two drachms of spirit of nitrous ether, three ounces of solution of acetate of ammonia and water to make up six ounces, the dose being half an ounce every four hours. This was afterwards changed to a powder containing one grain of sulphate of quinine, ten grains of citric acid, and some sugar of milk, given every four hours in half an ounce of a mixture containing two drachms of bicarbonate of potash, 36 grains of carbonate of ammonia, and half an ounce of syrup of orange dissolved in six ounces of water. The diet consisted of milk, broth, and eggs. The first named

2 On the Origin of the Sertoli or Foot-cells of the Testis, Walker and Embleton, Procceedings of the Royal Society. 1906.

3 Farmer, Moore, and Walker: On the Behaviour of Leucocytes in Malignant Growths, Transactions of the Pathological Society of London, 1905. Ibid., on the Cytology of Malignant Growths, Proceedings of the Royal Society, 1906.

4 See in THe LANCET, August 12th, 1905, a paper by Dr. G. F. Smith and Dr. A. Looss upon Matuha and his companions. Matuha's age was then estimated by various osteological data as about 18 years. 
was taken badly at first, as the patient had never tasted it before, but the addition of alcohol in the form of whi ky quite overcame this difficulty. During the fourth and fifth days the patient was very ill with great cyanosis and difficulty in breathing along with troublesome cough. The pulse became intermittent and oxygen and strychnine had to be administered and alcohol given freely. The case was a severe one but followed the usual course of an acute lobar pneumonia, the crisis occurring on the sixth day, when the temperature dropped from $103.8^{\circ}$ to $97.2^{\circ}$ in 18 hours. There was profuse sweating during this stage. There was a rise to $1022^{\circ}$ the following night, but after this the patient had an uninterrupted recovery.

An examination of the sputum (which had the typically rusty colour at first) was made by the Clinical Research Association and a certain number of pneumococci was found. An attempt was made to examine the blood for leucocytosis, but the difficulty in obtaining a specimen was so great that the idea had to be abandoned. No herpes was seen round the lips during the case. As may be imagined, the task of nursing was no light one and great credit is due to the nurse in charge of the case for the admirable way in which she managed the patient. The patient was very good throughout, although at first he was suspicious of everything done for him.

During the convalescence, which was a good one, the patient would sit for hours playing with his bow and spear, going through all the incidents of the chase. The whole case followed the course of an acate pneumonia in a white man, but the unusual type of patient has led me to report it. Beverley.

\section{INTERNAL SECRETION AND THE DUCTLESS GLANDS.}

By SWALE VINCENT, M.B. LoNd., D.Sc. Edin., PROFESSOR OF PHYSLOLOGY IN THE UNIVERSITY OF MANITOBA, WINNIPEG, CANADA.

\section{PART II.}

The Thyroid and Parathyroid Glands.

A. Effects of ablation and disease.-No attempt will be made to give a complete account of the history and literature of the thyroid gland. Our knowledge of the subject is not based upon so secure a foundation as a perusal of modern text-books would lead one to suppose and there can be little doubt that there bas been in some directions undue haste in correlating clinical experience with the results of experimental physiology. The present state of our knowledge has been reached throngh different modes of investigation, some of which will now be dealt with in order. As regards the effects of removal of the organs, perhaps the most generally accepted among recent views may be briefly stated as follows. As regards vital importance, the function of the thyroid gland is subsidiary to that of the parathyroids. Removal of all the parathyroids from an animal, even if the thyroid be left intact, invariably proves fatal within a short time, and this with typical nervous symptoms described under the name of "tetany." Removal of the thyroid, on the other hand, gives rise to an entirely different train of symptoms stated to be those of "post-operative mpxcedema" or of "cachexia strumipriva." 2 According to this modern cor ception, the divergent results obtained by the older experimenters in different classes of animals were apparent rather than real, they having failed to appreciate the anatomical differences, and having, in fact, performed a different operation in each case. This theory of the supreme importance of the parathyroids was first put forward by Gley ${ }^{3}$ who rediscovered the (external) parathyroids ${ }^{4}$ but was more definitely formulated and elaborated by Vassale and Generali. ${ }^{.}$The extreme

I Part I. was published in The Lancet of Augnst 11th, 1906, p. 348. 2 Kocher, Archi tiir Klinische Chirurgie, 1883, Band xxix., S. 254 Reverdin, Revue Médicale de la Suisse Romande, 2eme année, 1882, p. 539 ; 1883, Nos. IV.-VI., p. 169 ; 1887. pp. 275, 318

Comptes Rendus de la Société de Biologie 1891, p. 843

4 These bodies were first described by Saniström, Upsala, Läkareföremings Formandlingar, 1880, Band $\mathrm{xv}$. Reference in Schmidt's Jahrhwis. 1830; Hofmann-Schwalbe's Jahresbericht, 1881; Firchow (

Arivente, 1896, vol. i.. fasc. 3 and 7; Archives Italieumes de Biologie, 1896, tomes xxv. and xxvi., p. 459. importance to life of the parathyroids has also been affirmed by Rouxeau, ${ }^{8}$ Moussu, ${ }^{7}$ Welsh, ${ }^{8}$ and Capobianco and Mazziotti. "The question as to the extreme importance of the parathyroids cannot yet be considered as settled. Kisbi ${ }^{10}$ found that dogs and cats often die although the parathyroids be left behind. Vincent and Jolly 11 found further that removal of all four parathyroids wis not necessarily fatal. We were furthermore unable to confirm some other statements which are very commonly accepted. The general conclusions reached were as follows: " 1 . It cannot be truly said that either thyroids or parathyroids are essential for life, since it is frequently possible to remove either or both without causing death. 2. We find, as others have done, that fatal results when they occur are not due to injuries to surrounding structures accompanying the surgical interference but must be referred to absence of the glands in question ${ }^{12} 3$. No statement, universally applicable throushout the animal kingdom, can be made as to the importance of the glands in question, whose functions appear to differ very widely in different classes of animals. Rats and guinea-pigs do not seem to suffer at all as the result of extirpation. ${ }^{13}$ Monkeys only show transient nervous symptoms. ${ }^{14}$ Dogs and cats fre. quently, but by no means invariably, suffer severely and die. In foxes symptoms come on with remarkable rapidity and death is correspondingly early. 4. The diversity of results obtained in different classes of animals is not to be attrituted to anatomical but to physiological differences. 5. In no animal have we been able to induce symptoms resembling myxoedema. ${ }^{15} 6$. In young animals, although extirpation of the thyroid causes a temporary cessation of growth, we find that this is not necessarily accompanied by symptoms of a cretinoid nature. 7. Myxœdema and cretinism must then, we think, be due to causes more complex than simple thyroid insufficiency. 8 . When the thyroid is removed the parathy roids appear capable of functionally replacing it to a certain extent and their histological structure changes accordingly."

Perbaps the point of most general interest in the above results is that mysodema was never induced, even in monkeys. This result differs from that obtained by Horsley, ${ }^{16}$ Murray, ${ }^{17}$ and Edmunds, ${ }^{18}$ who state that it is possible by operation to induce myxodema in monkeys. Our animals were kept at ordinary indoor summer tem. perature and they showed no symptoms which could be described as myxodematous. In some cases it was impossible to distinguish the operated monkeys from the controls and in a photograph which was taken of an operated animal and a normal one side by side the operated animal looked the healthier of the two. One of the animals, it is true, suffered three days after the operation from slight muscular tremors but completely recovered. Some of them suffered from catarrh and one died from some laryngeal affection and it seems probable that, as in the case of other animals, removal of the thyroid gland leaves monkeys in a condition in which they are less capable of resisting disease. We do not pretend that the monkeys were quite unaffected by the operation. They were, as a rule, perhaps somewhat

\footnotetext{
6 Comptes Rendus des Séances de la Société de Biologie, 1897, p. 17. Ibid., p. 44

Journal of Anatomy ar d Physiology, 1898, p. 401; Journal of Pathology and Bacteriology, 1899

9 Gionnale Interuationale delle Scienze Mediche, 1899, anno xxi. 10 Virchow's Archiv, 1904, Band clxxvi., S. 260 1 Journal of Physiology, vol. xxxii., 1904.

12 This was the result of some few experiments in which injury to surrounding structures was done without removal of either thyroids or parathrroids. No typical symptoms were observed in these cases but there is still a possibility that if a larger number of experiments wero performed and the necessary conditions were understood some the nervous symptoms may after all not be due to absence of the glands. This possibility is suggested by i he fact chat tetany may com on at variable periods from five hours to a week after operation.

13 Such extirpation including parathyroids as well as thyroids.

1: In a new series of observations by Mr. Jolly and myself. the results of which have not 5 et been published, one monkey died within 24 hours after the operation with a hat appeared to be typical tetany. It was
found, however, post mortem that the recurrent nerve and other strucfound, however, post mortem that the recurrent
tures had been included in one of the ligatures.

15 I.e.. there has been no swelling of the subcutaneous tissues

15 I.e.. there has been no swelling of the subcutaneous tissues.
16 Proceedings of the Roval Socit ty, 1884, No. 435 , and 1886; Brit. Med. Jour, Jan. 17th and 31st, 1885; Internationales Centralblatt für Maryngologie. July, 1885; Comptes Rendus des Séances de la Société de Biologie. December, 1885; Report of the Myxodema Committee of de Biologie. December, 1885; Report of the Myxoedema Committee of Brit. Med Jour., Feb. 8th and July 26th, 1890; Internationale Beiträge Brit. Med Jour., Feb. 8th and July 26th, 1890 ; Internationale If Diseases of the Medicin, Virchow's Fest schrift, i, 1891.

Journal of Pathologv, vols. iii., v.. vi.. and vii., 1896-1900; the 18 Journal of Pathologv, vols. iil., v. vi.. and vil., 1896-1900; the
Pathology and Diseases of the Thyroid Gland, Edinburgh and London,
} Patho
1901 . 